\title{
現代日本の住宅設計論にみられる「箱」という言葉に投影された建築家の思考

\author{
A STUDY ON THE FRAMEWORK OF ARCHITECTURAL THOUGHTS WITH THE WORD \\ "BOX" AS A DESIGN THEME OF CONTEMPORARY JAPANESE HOUSES
}

\author{
塩 崎 太伸*, 内藤麻 美**, 四ヶ所 高志 ${ }^{* * *}$, 奥 山信 一 $* * * *$ \\ Taishin SHIOZAKI, Asami NAITO, Takashi SHIKASHO \\ and Shin-ichi OKUYAMA
}

\begin{abstract}
The aim of this study is to clarify the framework of architectural thoughts with the word "box" through analyzing design theories of contemporary Japanese houses. Firstly the conceptural recognitions for "box" are classified into four categories (Simplicity, Unitarity, Primordiality, and Histricity) through analyzing articles written as design theory for houses by architect. Secondly the organization forms of "box" are analyzed from two aspects. The one is the characteristics of "box" which is classified into Mass type and Volume type, and the other is the operations on "box" which shows the number of "box" to operate or not to operate. Finally relations between the conceptural recognitions and the organization forms of "box" are analyzed totally including a chronological consideration.
\end{abstract}

Keywords : box, analogy, house, terminology, architects' discourse

箱, アナロジー, 住宅, 概念設定, 建築家の言説

\section{1 序}

\section{1 背景と目的}

ル・コルビュジエが、新たな時代の建築像としてサヴォア邸を「空 中に浮かぶ箱」 ${ }^{1)}$ と表現した例や、日本において試みられている「箱」 をテーマとした住宅作品注 ${ }^{1)}$ などの例のように、「箱」という言葉 は建築家が設計論を展開する際に自身のコンセプトを投影し得る重 要な概念となっていると考えられる。このことは「箱」という言葉 が、単純な面により構成された形態としての量塊的・幾何的特徵を 示すと同時に、内部に気積をもった入れ物としての容器的・空間的 特徴をあわせ示すことから、建築の抽象モデルのひとつとして、さ まざまなイメージを内包しうる概念であるためと考えられる。こう した「箱」の $2 つ の$ 側面を独立して認識することは、直方体のよう ないわゆるボックス形状の形態的特徴をもたずとも、「箱庭」のよ うに浅い盆の上につくられた種々の要素を含む世界を成立させる枠 組みに対し「箱」という言葉が用いられる例を見出せるように、我々 の慣習としても一般的と言える注2)。また、表意文字である漢字を 用いる日本においては言葉のもつ意味の多様性が漢字の種類数にあ らわれることがある。例えば「はこ」と読む漢字は「箱」「函」「笘」、 「匣」「筐」と数種類有り注 3 、日本文化における「はこ」的なモノ あるいは概念への洞察の歴史が同える。そこで本研究では、「箱」 もしくはそれに類する言葉注 4$)$ を用いて設計の主題を提出している
論説を資料とし、その内容を検討することで、建築の抽象モデルの ひとつとしての「箱」という言葉に投影された建築家の思考の広が りとその射程を捉えることを目的とする。筆者らは既報論文 ${ }^{4)}$ に おいて建築家が「空間」という言葉を用いた創作概念によって自身 の設計論を組み立てる事例について考察した。本研究における「箱」 という言葉を用いた設計論の組み立ては、そうした検討の延長上に ある。「空間」が曖昧で多義的な言葉であるが故に建築家がさまざ まな主題を投影して設計論を組み立てていたように、本研究で検討 する「箱」という言葉も建築家のさまざまな主題が投影されている ことが予想される。

\section{2 資料}

本研究では、現代建築家が「箱」にどのような自身の設計論を投 影してきたかについて、その思考の枠組みを捉えることが目的であ る。そこで「箱」という言葉と設計論の主題が密接に関わる資料と して、作品名、論説名、あるいは論説中に「箱」もしくはそれに類 する言葉注 4$)$ が含まれ明確に主題が投影されているもの、論説中の 「箱」という言葉が字体や引用符で強調されているもの（箱、“箱” など）を資料としている。また、本研究においては資料となる論説 を住宅の設計論に限定している。これは、「箱」という言葉を用い た設計論の対象となるビルディングタイプが多岐にわたるなかで、 住宅がその規模から全体性を認識しやすいことと、日常生活の器と

\footnotetext{
本論文は 2010 年度建築学会大会学術講演会で発表されたものを修正してまとめたものである。

* 東京工業大学大学院 助教・博士 (工学) Assist. Prof., Dept. of Architecture and Building Engineering, Tokyo Tech, Dr. Eng.

** 新建築社 修士 (工学)

*** 福岡大学 助教・博士 (工学)

**** 東京工業大学大学院 教授・博士 (工学)

Assist. Prof., Dept. of Architecture, Fukuoka University, Dr. Eng.

Prof., Dept. of Architecture and Building Engineering, Tokyo Tech, Dr. Eng.
} 
して認識されうることから、量塊性や容器性注5) のような「箱」と いう言葉のもつ特徴と関連した思考が投影されやすいと推察される ためである。資料の年代は戦後から現代までを対象とし、言説の抽 出にあたり、戦後の建築ジャーナリズムの中で最も代表的と思われ る「新建築」誌、新建築住宅特集」誌、「都市住宅」誌、建築文化」 誌に掲載された設計論を中心として先に述べた基準のもとに資料の 選定を行った結果、表 1 に示す 113 資料を分析の対象とした。なお、 本論においては建築実体の表現と同様に、建築家の言語による表現 活動がそれ自体でひとつの意味のある体系をつくり出していると捉 えるものである。そのため、実体表現と言語表現の一致不一致は問 題とせず、分析においては設計者自身によって著された言説のみを 用い、図面や写真は分析の対象としていない。

\section{3 既往研究}

本研究と関連する既往研究として、まず、建築家の言説を総体的 かつ相対的に検討する研究があげられる。特に本研究と関連の高い ものに特定の言語内容に着目する研究と主題の意味内容に着目する 研究がある。前者では佐々木、山田らによる住宅設計の与条件と建 築のイメージに関する言説についての研究 ${ }^{6)} や 、$ 竹内、岩岡らに よる建築におけるスケールの概念に関する研究 ${ }^{7}$ にみられるよう な、建築設計における重要な側面に焦点をあて建築家がどのような 記述をしているかを研究するものがあり、これらは报う主題こそ異 なるものの、建築家の言説活動を実体である建築物の設計活動と同 様に表現活動の 1 つとして捉え、その意味の広がりを検討する試み として成果を上げている。後者では筆者らによる、建物の用途ある いは構成などを限定した上でその限定した事柄についての建築家の 設計論の主題を検討するもの ${ }^{8)}$ がある。次に、建築における鍵概 念について検討する研究として、F. L. ライトの建築思想における 諸概念についての水上の一連の研究 ${ }^{9)}$ 、アルド・ファン・アイクの 建築思想における諸概念についての朽木の一連の研究 ${ }^{10)}$ 、建築の 概念における機械のアナロジーについての川道の研究 ${ }^{11)}$ などがあ り、建築設計における思想や概念を、対応する建築との関連を考慮 に入れた上で詳細に検討した研究として成果を上げている。また、 「箱」という言葉に着目した研究について検討すると、論文タイト ルに「箱」という語の含まれる日本建築学会の計画系論文は 1936 年から 2014 年までにおいて 10 事例発表されており、そのうち 5 論文が箱庭に関する論文、3 論文が箱柱式教会に関する論文、さら にル・コルビュジエの作品のタイプ分けに「箱枠型」という言葉を 使った論文と李箱（韓国文学作家）に関する論文が 1 編ずつあるの みであった。これらのいずれも「箱」という概念の意味内容につい て深く検討するものではない。また、1966 年から 2014 年までの 日本建築学会大会発表梗概集に扔いても箱木家住宅についての 1 件 と本論文の関連論文である筆者らの 2 件 ${ }^{12)}{ }^{13)}$ 以外は上述した内容 の論文しか見られなかった。以上より、建築意匠論・計画論分野に おいては「箱」と建築設計との関連を意味論的に考察した既往研究 は未だ無いといえる。

なお、建築分野における「箱」に関連した論説としては、横山正 による『箱という劇場』2)（1989 年）、磯崎新による「政治的であ ること」 ${ }^{14)}$ (1998 年)、田中純による「箱をめぐる戦略一都市のレ ディ・メイド」3) (2001 年)、などがあげられる。また、「箱」と いう言葉を作品名に含んだ連作を展開している建築家として、宮脇
表 1 資料リスト

\begin{tabular}{|c|c|c|c|c|c|c|c|c|}
\hline 掦聂 & 作品名 & 建然家 & 唃菜生 & & & & & \\
\hline & 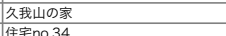 & 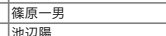 & & & & & & \\
\hline $\begin{array}{l}2 \begin{array}{l}2 \\
3 \\
3\end{array} \text { SK } 57002 \\
5703\end{array}$ & 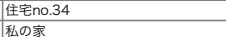 & 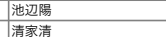 & $\frac{A}{A}$ & & & & $\begin{array}{ll}v \\
v\end{array}$ & \\
\hline 4 SK 6804 & 石电酣 & 铨木柏 & & $\mathrm{DD}$ & & & & \\
\hline $\begin{array}{l}5 \text { SK } 7002 \\
65 \text { S 7006 } \\
\end{array}$ & 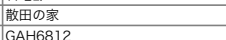 & $\begin{array}{l}\text { 坟本一成 } \\
\text { s.t. }\end{array}$ & A & 80 & & & $\mathrm{v}$ & \\
\hline $7 \mathrm{SK} 7104$ & 水永無瀨的时家 & 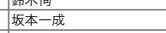 & A & & & & & \\
\hline $\begin{array}{l}85 K 7110 \\
9567110 \\
\end{array}$ & 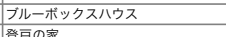 & 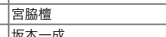 & $A_{A}$ & & $E E$ & & $\mathrm{M} / \mathrm{N}$ & \\
\hline 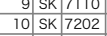 & 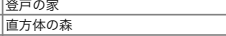 & 微原一原一男 & & & E & & & \\
\hline $11 \mathrm{SK} 7202$ & 点洋山の家 & アトリIR & $B$ & & & & M & \\
\hline 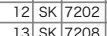 & 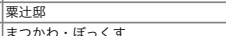 & 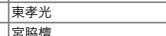 & $\mathrm{AB}$ & $D$ & & & & \\
\hline $14 \mathrm{~KB} 7211$ & 反住器 & 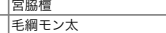 & & $\mathrm{c}$ & \begin{tabular}{|l|l}
$E$ \\
$E$
\end{tabular} & - & $\frac{M N}{M N}$ & \\
\hline $155 \mathrm{SK} 7307$ & <WORK5>䦕力れた空の象 & 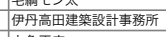 & & D & & & $\mathrm{v} v$ & \\
\hline $\begin{array}{ll}16 & \text { TJ } 7603 \\
17 \text { TT } 7608 & \end{array}$ & 心相铝 & 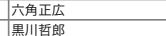 & $\begin{array}{l}A \\
A\end{array}$ & & & & \begin{tabular}{|lll}
$v$ \\
$v$
\end{tabular} & \\
\hline 18 TJ 76012 & 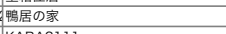 & 签剑边道子 & & $\mathrm{c}$ & & & $\mathrm{v}$ & \\
\hline 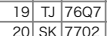 & 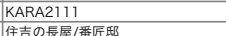 & 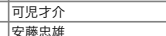 & AA & & $\mathrm{EF}$ & & $\mathrm{MN}$ & \\
\hline 21 Sk 7707 & 成城の白い家 & 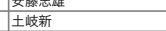 & & & 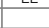 & G & & \\
\hline $22 \mathrm{SK} 7708$ & 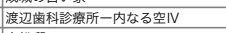 & 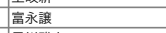 & B & $\mathrm{c}$ & & & & \\
\hline $\begin{array}{rl}23 & 3577908 \\
24 \text { SK } 7908 & \end{array}$ & 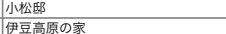 & 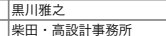 & & $\mathrm{C}_{\mathrm{C}}$ & $F$ & & $\frac{\mathrm{M} / \mathrm{N}}{\mathrm{v}}$ & \\
\hline 25 KB 7910 & 慓紫住宅0001 & 湾边豊和 & & & & G & M & \\
\hline 26 SK 8102 & 己㝥の家 & 林上琙 & A & & E & & & \\
\hline $\begin{array}{l}27.5 \mathrm{SK} 8102 \\
28 \mathrm{ST} 8102 \\
\end{array}$ & 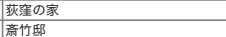 & 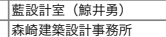 & $\begin{array}{cc}A A \\
B\end{array}$ & $D$ & & & & \\
\hline $\begin{array}{l}29 \\
29 K\end{array} 8104$ & 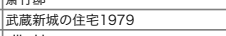 & 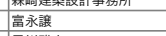 & & & E & G & $\mathrm{M} / 1$ & \\
\hline 30 SK 8104 & & 黑川倠之 & & & E & G & & \\
\hline $\begin{array}{l}31 \text { SK } 8104 \\
32 \text { TI } 81099\end{array}$ & 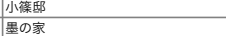 & 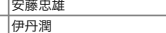 & $\mathrm{B}$ & & & $\mathrm{H}$ & 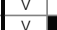 & \\
\hline $\begin{array}{l}33 \text { TJ } 8211 \\
345208\end{array}$ & 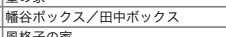 & 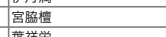 & AB & D & & & $\mathrm{v}$ & \\
\hline 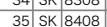 & 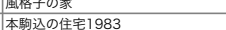 & 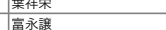 & \begin{tabular}{|l|l|}
$A B$ \\
$B B$
\end{tabular} & & & & $\frac{V N}{M / N}$ & \\
\hline $36 \mathrm{SK} 8411$ & 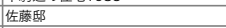 & 城池秀人 & & D & & & $\mathrm{V}$ & \\
\hline 37 JT 8710 & M氏の住居 & 内藤廣 & $B$ & & & & & \\
\hline 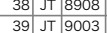 & 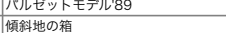 & 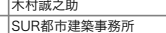 & $\begin{array}{l}\text { A } \\
\text { B }\end{array}$ & $c$ & & - & $\frac{\mathrm{M} / \mathrm{M}}{\mathrm{M}}$ & \\
\hline 40 JT 9009 & HAH & 白旗是幸 & & D & & & $y$ & \\
\hline $\begin{array}{ll}41 \text { JT } 9102 \\
42\end{array}$ & 上京の家 & 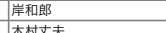 & 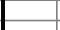 & & 5 & G & $\mathrm{v}$ & \\
\hline $\begin{aligned} 422 \text { ग ग } 9107 \\
43 \text { JT } 9203\end{aligned}$ & 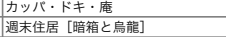 & $\begin{array}{l}\text { 不林丈夫 } \\
\text { 中屟莧 }\end{array}$ & B & & $\mathrm{F}$ & 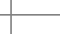 & V & \\
\hline 44 JT 9209 & 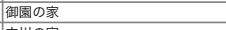 & 倾原義二 & $\mathrm{A}$ & & & & & \\
\hline $\begin{aligned} & 455 \text { J J } 9310 \\
& 46 \mathrm{JT} 9311\end{aligned}$ & $\begin{array}{l}\text { 童川傢 } \\
\text { SYAPSE }\end{array}$ & $\begin{array}{l}7 ー \text { } \\
\text { 获子田枯幸ッフ }\end{array}$ & BB & D & & - & 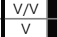 & \\
\hline 47 TT 9411 & WEB. HOUSE & 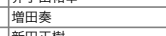 & $\mathrm{B}$ & & & & $\mathrm{v}$ & \\
\hline $\begin{array}{rl}48 & \text { JT } 9501 \\
499 & 9508 \\
\end{array}$ & $\begin{array}{l}\text { 豊中の方舟 } \\
\text { A H HOS HOUSE HOSE }\end{array}$ & 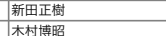 & & & $\frac{F}{F}$ & 6 & $\mid v N$ & \\
\hline 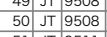 & 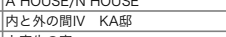 & \begin{tabular}{|l}
$\lambda$ 江正之 \\
\end{tabular} & & cc & & & $\mathrm{M} / \mathrm{M}$ & \\
\hline $\begin{array}{ll}51 \text { JT } 9511 \\
520603\end{array}$ & 步麻生生家 & 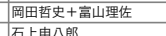 & $B$ & c & & G & $\frac{V N}{M}$ & \\
\hline 53 JT 9604 & 箱D场D家 & 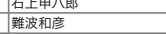 & B & & $\mathrm{F}$ & G & $\mathrm{VN}$ & \\
\hline 54 JT 9604 & 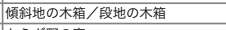 & 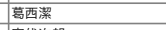 & A & & $F$ & & & \\
\hline $\begin{array}{ll}556 \text { JT } 9606 \\
56 \text { J } 9608 \\
\end{array}$ & 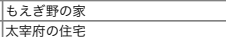 & 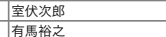 & & $\begin{array}{l}D \\
C\end{array}$ & & $\square$ & \begin{tabular}{|l}
$v$ \\
$M$
\end{tabular} & \\
\hline 57 JT 9609 & FOX & 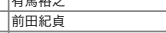 & $\mathrm{B}$ & & & - & $\mathrm{m}$ & \\
\hline 58 IT 9703 & 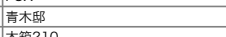 & 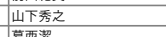 & As & c & & & v & \\
\hline 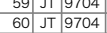 & 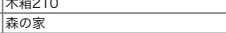 & 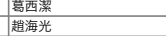 & $A A$ & D & $\mathrm{F}$ & & $\mid v N$ & \\
\hline 61 TT 9706 & まんほうう1997 & 岡田㫪史十富山理佐 & & & & G & M & \\
\hline 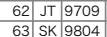 & $\begin{array}{l}\text { ONE BOX 家 I. II } \\
\text { Nisino Office }\end{array}$ & 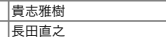 & A & & & $G$ & \begin{tabular}{l|l}
$v$ & \\
$M$ &
\end{tabular} & \\
\hline 64 JT 9807 & WHITE CUBE & 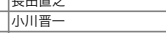 & & & $E$ & & $\frac{\mathrm{m}}{\mathrm{v}}$ & \\
\hline 65 JT 9810 & 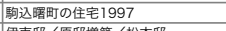 & $\begin{array}{l}\text { 富永境 } \\
\end{array}$ & A & c & & 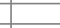 & $\mathrm{V} / \mathrm{N}$ & \\
\hline $\begin{array}{ll}666 \\
67 \text { JT } 9903 \\
69904 \\
\end{array}$ & 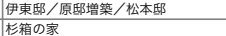 & 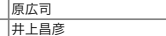 & BB & c & & 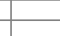 & $\frac{M}{M / N}$ & \\
\hline 68 JT 9907 & 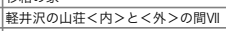 & 入江轰一 & $\mathrm{B}$ & & & 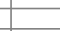 & $\mathrm{v}$ & \\
\hline $\begin{array}{ll}69 & \text { SK } 9908 \\
7 \text { 70) TI } 9908\end{array}$ & 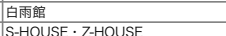 & 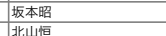 & & & & $G$ & $\frac{V}{M}$ & \\
\hline \begin{tabular}{l|l}
71 & JT 0003 \\
\end{tabular} & SH@64 & 宮本住明 & A & & & & $\frac{M}{M}$ & \\
\hline 72 IT 0003 & 東広島の住宅 & 岡河賣 & & & & $G^{G}$ & $M$ & \\
\hline 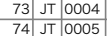 & $\begin{array}{l}\text { L } \\
\text { 西大泉のBox Culvert }\end{array}$ & 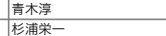 & $\frac{A}{A}$ & c & & 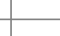 & \begin{tabular}{|c|c|c|}
$M$ \\
$V N$
\end{tabular} & \\
\hline 75 SK 0006 & 耝黑城キャンフ場コテージC倲 & 研大五 & & c & & & $\mathrm{v}$ & \\
\hline $\begin{aligned} & 766 \text { JT } 0009 \\
& 77 \text { TI } 0106\end{aligned}$ & $\begin{array}{l}K \equiv /+ \\
\text { WEB } \\
\text { W }\end{array}$ & 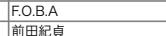 & & \begin{tabular}{|c|}
$c$ \\
$c$
\end{tabular} & & G & $\frac{M / 1}{v}$ & \\
\hline 78 JT 0107 & ホワイトボック & $\begin{array}{l}\text { 湅田猚春 } \\
\end{array}$ & $\mathrm{B}$ & & & & $\mathrm{v}$ & \\
\hline $\begin{array}{ll}79 & \text { JT } 0107 \\
\end{array}$ & 開放的な大箱 & 第酩潈 & A & & & & v & \\
\hline $\begin{array}{ll}80 \mid \mathrm{JT} 0112 \\
81 \mathrm{TT} 0202\end{array}$ & 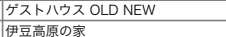 & 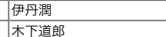 & & c & & $G$ & $\frac{v}{v}$ & \\
\hline 82 IT 0203 & Basic Box-01 & 䜊解 & AA & & & 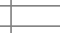 & 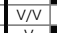 & \\
\hline \begin{tabular}{rl|l}
83 & JT 0207 \\
84 TI 02028 &
\end{tabular} & 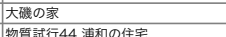 & 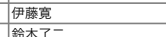 & $B$ & & & $G_{0}$ & 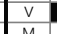 & \\
\hline 85 JT 0211 & 連空の家\#3 & 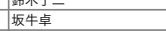 & & & $\mathrm{F}$ & & $\mathrm{v}$ & \\
\hline 86 JT 0302 & 干川・スクリーンの家 & 田井幹夫 & A & & & & & \\
\hline 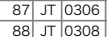 & 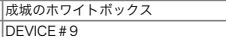 & 金一- & $B$ & & & G & $\frac{v}{v}$ & \\
\hline 89 JT 0308 & 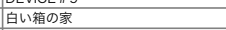 & 离安象一 & $\mathrm{B}$ & & & . & v & \\
\hline $90 \mathrm{JT} 0309$ & 找花茶屋の黒い箱 & 田期头 & A & D & & & & \\
\hline 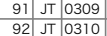 & 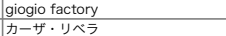 & 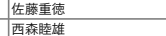 & B & $\mathrm{D}$ & $F$ & & $\frac{\mathrm{M} /}{\mathrm{v}}$ & \\
\hline 93 JT 0406 & $T \cdot$ BOX & 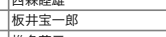 & & $\mathrm{c}$ & & & 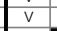 & \\
\hline 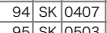 & $\begin{array}{l}\text { 直方の海 } \\
\text { TH }\end{array}$ & 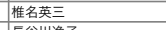 & $\mathrm{B}$ & $c$ & & & & \\
\hline 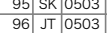 & $\begin{array}{l}\text { THOHOUE } \\
\text { 中野の住坴 }\end{array}$ & 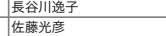 & & $\frac{D}{C}$ & & - & M & \\
\hline $97 \mathrm{~J}$ & 田の字のハコ & 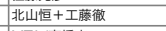 & & $\mathrm{C}$ & & & $\mathrm{v}$ & \\
\hline 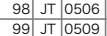 & $\begin{array}{l}\frac{1}{1} \text { 重的家 } \\
\text { HARKO }\end{array}$ & 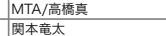 & A & $D$ & & & $\frac{V}{M}$ & \\
\hline 100 JT 0601 & 高化寺の住処 & 奥山信 & & & $\mathrm{F}$ & $\longrightarrow$ & $\mathrm{v}$ & \\
\hline $\begin{array}{ll}101 & \text { JT } 0603 \\
102 & 0603 \\
\text { TI } 0604\end{array}$ & $\begin{array}{l}\text { UNABB } \\
\text { TOWER HOUSE }\end{array}$ & 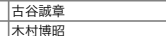 & $A B$ & & $F$ & $G$ & $\frac{v}{M C}$ & \\
\hline $\begin{array}{l}102 \\
103\end{array}$ & moving box & 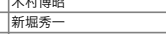 & & $\mathrm{cc}$ & & & $\mathrm{M} / \mathrm{N}$ & \\
\hline $104 \mathrm{SK} 0612$ & CREAM & 沲田昌弘一福島加津 & & C & & & $\mathrm{v}$ & \\
\hline $\begin{array}{l}1055 \mathrm{SK} 0703 \\
106\end{array}$ & 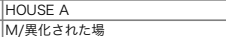 & $\begin{array}{l}\text { 西沢立盛 } \\
\text { 有䮦之 }\end{array}$ & & $\frac{C \times D}{D}$ & & & $\frac{v}{v}$ & \\
\hline 107 JT 0802 & Rainbow House & 今永和利 & & $\mathrm{c}$ & & & M & \\
\hline 108 SK 0809 & house $\mathrm{N}$ & 藤本侍介 & . & $\mathrm{D}, \mathrm{C} \times \mathrm{C}$ & & & $\mathrm{V} / \mathrm{N}$ & \\
\hline 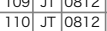 & 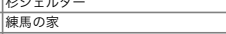 & 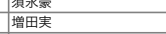 & & $\mathrm{CD}$ & & & & \\
\hline $\begin{array}{ll}111 & \text { SK } 0901 \\
1122\end{array}$ & $\begin{array}{l}\text { House before House } \\
t 5 \times 0 \text { ( }\end{array}$ & 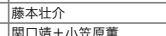 & $A$ & $C D$ & & & $M N$ & \\
\hline $\begin{array}{l}112 \mid \mathrm{TJ} / 0905 \\
113 \mathrm{SK} \\
09912\end{array}$ & 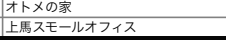 & 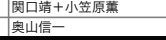 & A & & $\mathrm{F}$ & & $\frac{M}{M}$ & 童 \\
\hline
\end{tabular}

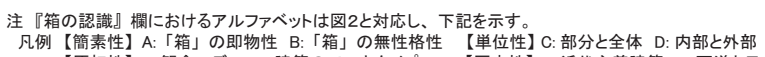

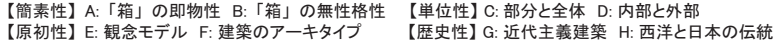


檀 (《ボックス》シリーズ注1) 、難波和彦(《箱の家》シリーズ注1) 、 葛西潔 (《木箱》シリーズ注1) $)$ があげられる。

\section{4 研究の概要}

図 1 の分析例 No.53-1 では建築のモデルを空間の初源的な状態 に見出し、それを「箱」という言葉であらわしている。また、「洞 窟的空間を発見出来る余白を備えた…と述べているように、その 際に思考している「箱」が容器性を備えたものであることが読み取 れる。本研究では資料となる論説からこのような読み取りを行い、
「箱」という言葉を用いて思考される内容について、「箱」のどのよ うな側面に着目するかといった『箱の認識』と、「箱」をどのよう に構成するかといった『箱の構成形式』との大きく 2 つ水準から 捉え検討する。

第 2 章では設計論から抽出した『箱の認識』の意味内容の広がり を KJ 法注 6 ) を用いて検討、整理する。複数の『箱の認識』が読み 取れる場合はそれらの組合せを検討する。第 3 章では「箱」を具現 化する際に着目する側面について、量塊的性格の強いマスと容器的

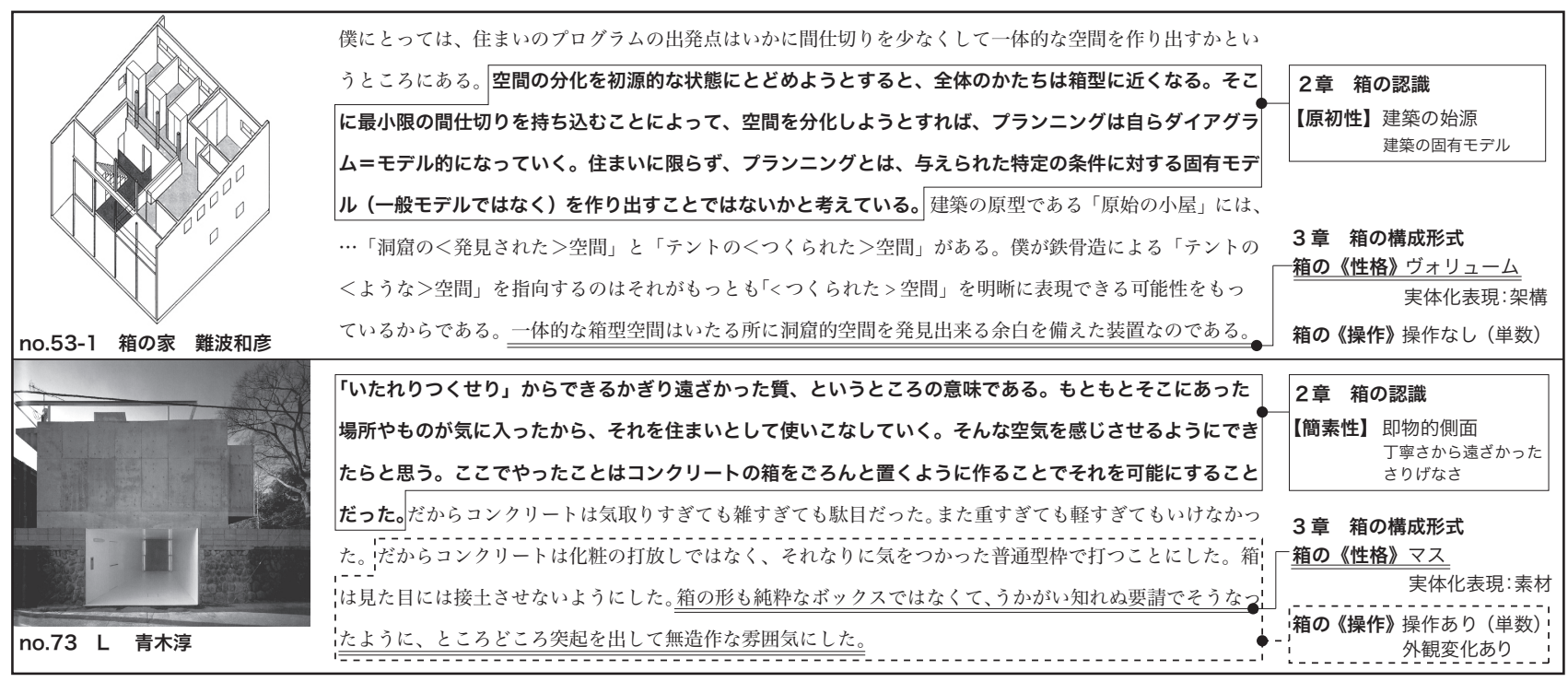

図 1 分析例（『箱の認識』『箱の構成形式』の抽出）注：図中の図面、写真は分析対象ではない。

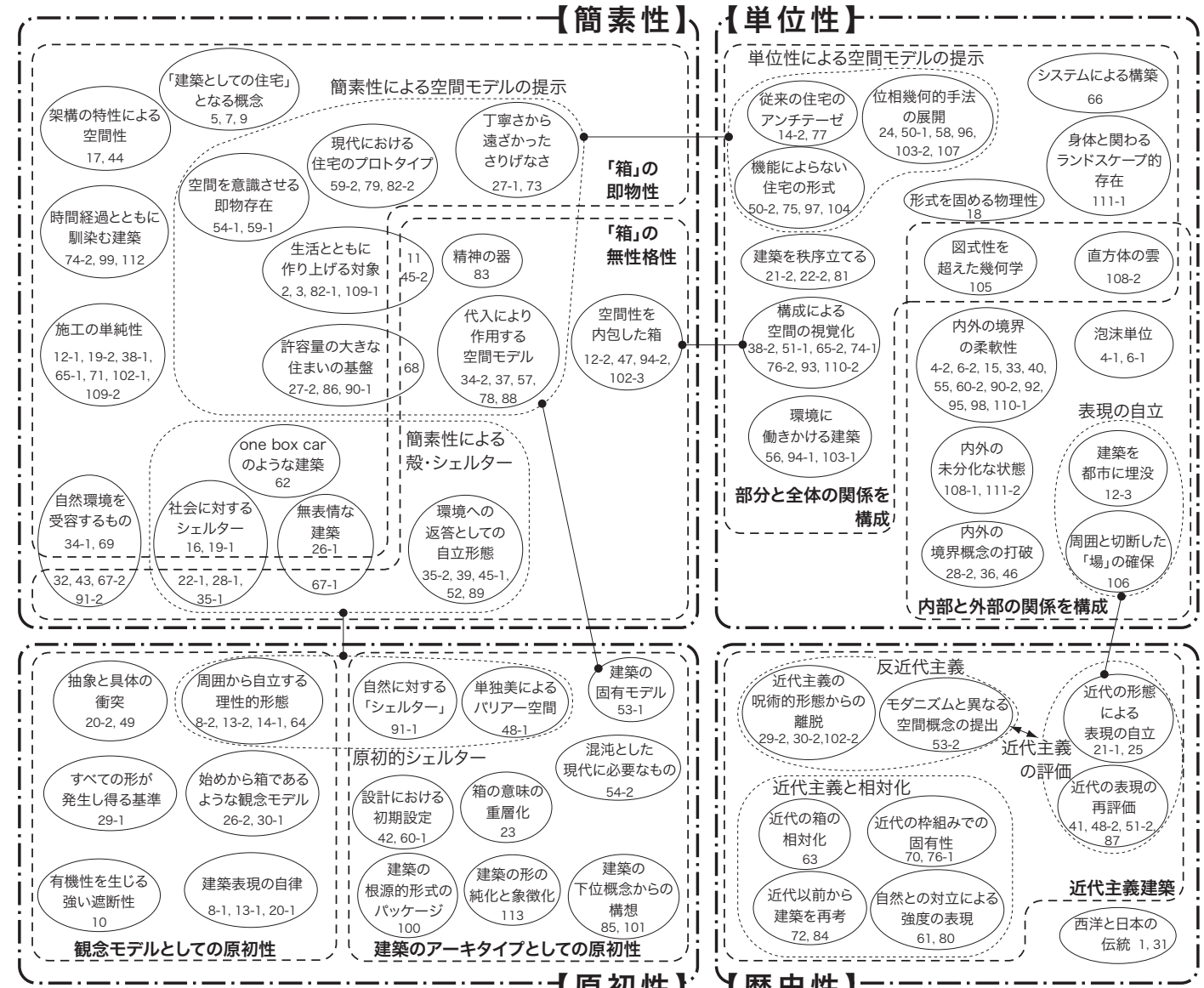

図2 『箱の認識。

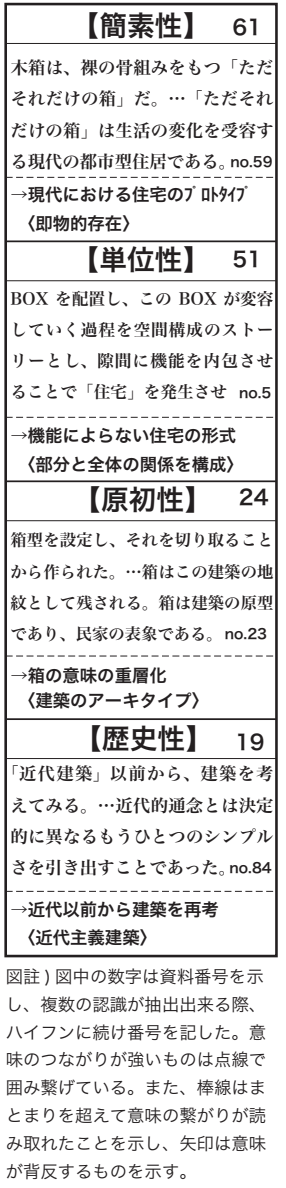

一原初性】歴史性】 み取れたことを示し、矢印は意味 が背反するものを示す。 
性格の強いヴォリュームとのふたつから捉え、それらを「箱」の《性 格》として位置づける。さらに、具現化の際に「箱」に変形や分割 などの操作を加えるか否か、および扱う「箱」の数を捉え、これら を「箱」に対しての《操作》として位置づける。そしてこれら《性 格》と《操作》との組合せから『箱の構成形式』を検討する。第 4 章では『箱の認識』と『箱の構成形式』との関連を総体的・相対的 に検討するとともに、通時的な考察を加え、第 5 章で結論を述べる。

\section{2 『箱の認識』}

建築家が「箱」という言葉を用いて設計論を展開する際、さまざ まな視点から「箱」を認識し、自身のコンセプトを投影している。 前章において図 1 の分析例で述べたような『箱の認識』を全資料か ら抽出しその内容を比較検討した結果、それらを大きく【簡素性】、 【単位性】、原初性】、歴史性】の 4 つの水準に分類した（図 $2^{\text {ì } 7)}$ )。

【簡素性】はさまざまなイメージを許容し得る下地として「箱」 を捉えるものであり、「箱」のニュートラルな無性格性を認識する ものと、「箱」そのものの即物性を認識するものとがみられた。ま ず、「箱」の無性格性の認識では、「凹凸の少ない単純形態、閉じた 箱型」(no.91-2, 2003) 注8) のように、「箱」の物質感を排除した 無性格な状態を自然現象や多様な生活を受けとめるものとして捉え るもの、「単純な箱として混乱した風景に置かれている。…意図的 に住宅の記号性が略奪され倉庫のような素っ気ないものになってい る。」（no.45-1，1993）のように、意味が消去された「箱」の状態 を意味の過剩な社会や環境に対するシェルターとしての役割として 求めるもの、「外観は単純なタワー状の白いボックスであるが、内 部はその印象に反している。（no.102-3, 2006）のように豊かな 内部空間との対比を無表情な外観をもつ「箱」に求めるものなどが みられた。次に、「箱」の即物性の認識では、「構造と外皮だけの剥 き出しの木箱があらわれる」(no.59-1, 1997)、「まずコンクリート の箱だけつくって…（no.3, 1957) のように、「箱」を即物的な存 在として捉え、それにより生じる空間の強度を住まい手の生活へ託 すもの、「工業化の基本的手法、量産モデュール、組み立ての簡略 化などなどの極致は箱である。」(no.38-1, 1989) のように、施工 の単純性を「箱」に求めるもの、「絶望的に厚いコンクリートの箱 に封じ込めた」（no.16, 1976）のように、その物体としての閉鎖性 に社会や環境に対するシェルターとしての役割を求めるもの、「閉 じた箱〉は現代社会の矛盾と混沌とした文化世界に対する砦である」 （no.5，1970）のように、「箱」の内部に自身の空間概念を投影し、 住宅の社会的な意味の消去を求めるものなどがみられた。

【単位性】は建築を構成する単位として「箱」を捉えるものであ り、建築の部分と全体の関係を構成する単位として認識するもの と、内部と外部の関係を認識するものがみられた。まず、部分と全 体の関係としての認識では、「外側からの境界の中にどう内側をつ くっていくかということが主題であり、BOX（直方体）の形体を採 択した。」(no.50-1, 1995) のように、建築の全体ないしは部分に対 応する「箱」を始めに用意し、建築の全体から部分の関係までを論 じようとするもの、「住宅を建築家による正確でいささか堅苦しい 図面上の作業から、積み木遊びのようなもっと即興的なものに少し でも摇り戻す試み」(no.104, 2006) のように、遊戯的に「箱」を 変形させることで従来の住宅に対するアンチテーゼを示すもの、「諸 条件をなんらかの「秩序」のもとに整理しょう」(no.81, 2002) の ように、住宅の様々な機能をある決まった形のなかで秩序立てよう とする際に「箱」を持ち出すもの、などがみられた。また、これら の中には、はじめに 1 つの箱」を建築の全体として規定し、それ を分割して部分を生み出すものと、始めに部分に相当する「箱」を 準備し、その集合で建築の全体を構築するものとがみられた。次 に、内部と外部の関係としての認識では、「この透明な函は、光を より大量に取得すると同時に、明暗部からの眺めに多様な変化を 与える。（no.4-2, 1968）のように内外を境界づけるものとして 「箱」を配置するもの、「周囲と切り離された「場」を確保し、さら に外とパラレルに自立して生活」するために、「周辺に対して閉鎖 した「箱」をセット」(no.106, 2007) するというように、外部と 対比させることで内部を捉えるもの、「閉じた箱としてつくるので はなく、‥四方に広がる自然にとけ込むようなものにしたかった」 （no.95, 2005）というように、外部と積極的に関係をとろうとする ものとがみられた。

【原初性】は建築を構想するための普遍的なモデルとして「箱」 を捉えるものであり、幾何学などによる観念的なモデルとして認識 するものと、「原始の小屋」のように建築のアーキタイプとして認 識するものがみられた。まず、钼念的なモデルとしての誌識では、 「立方体はそれ自体何も意味しない箱である。そのプラトン的立体 は、観念的操作や、概念の純粋培養が容易であるだろう。」(no.141,1972）のように、住宅のもつ意味を捨て去った結果生まれる理 性的存在として「箱」を捉えるもの、「危険な一歩誤れば造形至上 主義になるような綱渡りをあえてしたのは、プライマリーを追求し たいというエゴがそこにあったからだ。」(no.8-1, 1971) のように、 建築表現の自律を「箱」に求めるもの、「プラトン的立体は…この 廃品集合的都市空間のなかで、環境の〈異化〉を期待しうるという 逆説があるに違いない。」（no.14-1, 1972）のように周辺環境に対 して建築を自律させるもの、「理性的形態による…抽象的な空間と 具象的な人間生活を刺激的に衝突させる」（no.20-2, 1977）のよう に、具体的な人間の生活を刺激するための装置として「箱」を捉え るものがみられた。次に、アーキタイプとしての認識では、「社会 や文化の差異を超えた集団的無意識と呼ばれる私たち人間の身体の 奥底に眠る建築の形の元型」(no.113, 2009) のように、建築の元 型として「箱」を捉えるもの、「誰もが心の片隅に携えているこう した身体感覚のいくつかを、単純な家の原型殼でパッケージしたい と思った。」（no.100, 2006）のように、「箱」に建築の象徵作用を もとめるもの、建築は一言で言えば「箱」である。人を包み込む箱。 それに対して…空は建築の下位概念である。（no.85, 2002) のよ うに、自身の思考の出発点としての役割を「箱」に託すものなどが みられた。

【歴史性】は「箱」のもつ歴史的意味あるいは文化・社会的意味 を参照対象として捉えるものであり、西洋の伝統と日本の伝統とを 比較する内容の 2 資料以外は、近代主義建築にまつわる事柄 (17 資料）であった。その中には、「ラウムプランの再評価」(no.51-2, 1995）や「現代の一瞬にして理解可能なフラットな建築へのアン チテーゼ」（no.87, 2003）などのように近代主義建築を対象とした 肯定的な認識（近代主義の評优）、「この建築のほとんどの機能を満 たしている箱型の部分も、あの近代建築の装飾をそぎ落としたあと 
の、四角い建築ではなく、始めから箱であるように作られたそれで ある。」(no.30-2, 1981）のように、近代主義建築を対象とした否 定的な認識（反近代主義）、「私たちが構想する建築は 20 世紀初頭 に提示されたモダニズムの枠組みの中にある。（no.70, 1999）や 「今の時点でモダニズムと同じ手札で何ができるのか、その方法を 考える方が僕にはリアリティがある。」（no.76-1, 2000）などのよ うに、近代主義を相対化しその延長に「箱」を捉える認識（近代主 義と相対化）が捉えられた。

ここで整理した 4つの認識について考察すると、【簡素性】およ び【単位性】は、意味の付着しない存在として「箱」を捉えるもの であり、それに対して、【原初性】および【歴史性】は、意味が内 在した存在として「箱」を捉えるものといえる。ここでの意味とは 先に位置づけたように、【原初性】においては、人間の意識に存在 する建築の原型であると同時に建築に根源的に宿るものであり、【歴 史性】においては、近代主義建築によって生まれた「白い箱」に代

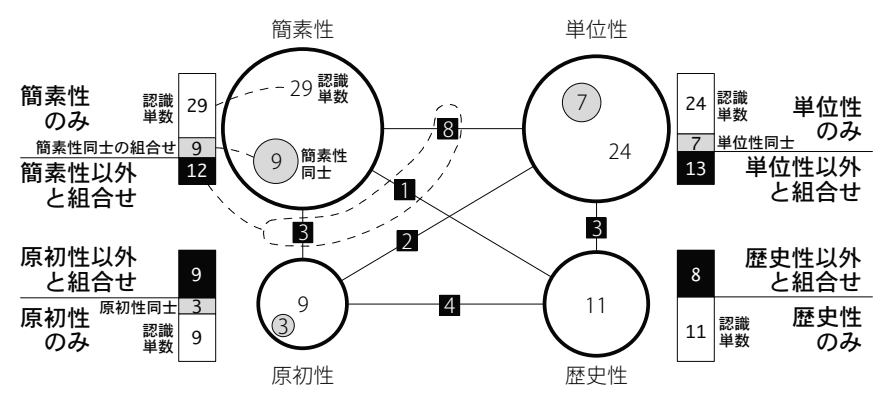

表されるような、建築の文化を通じて育まれるものと位置づけるこ とができる。資料の数の関係を検討すると（図 3 )、【簡素性】もし くは【単位性】のいずれかの認識がある資料は、【原初性】もしく は【歴史性】のいずれかの認識がある資料よりも数が多く、建築家 は「箱」という言葉を用いる際、意味の付着しない抽象モデルとし ての「箱」を設定し、思考を展開していく傾向があると考えられる。 また、後者（【原初性】、【歴史性】）においては他の『箱の認識』と 組み合わされる傾向が読み取れた。しかし、その組み合わされる認 識の内容には偏りがみられず、建築家は意味が内在した存在として の「箱」である【原初性】、歴史性】を思考する際、他の認識を加 えることで「箱」にもとから内在している意味を重層化させ、「箱」 に強度をもたせるという思考があらわれていると考察できる。

\section{3 『箱の構成形式』}

\section{3-1「箱」の《性格》と《操作》}

$\mathrm{H} \mathrm{R}$ ・ヒッチコックと P・ジョンソンは著書 ${ }^{16)}$ において、「これ までの建築の主要な質であった量塊の効果、静止した堅固さの効果 はほとんど消え失せた。ヴォリュームの効果、もっと精確にいうな ら、ヴォリュームを境界づける平坦な表面の効果がそれに取って替 わったのである。建築の主要な象徵はもはや厚い煉瓦ではなく、開 いた箱なのである」と述べ、インターナショナル・スタイルの第一 原理として、ヴオリュームとしての建築を提唱した。本研究では、 密実な量塊として「箱」を捉え、その形態的性質を思考するマスと、 境界づけられた空間として「箱」を捉え、その容器的性質を思考す

図 3 『箱の認識』の組合せ

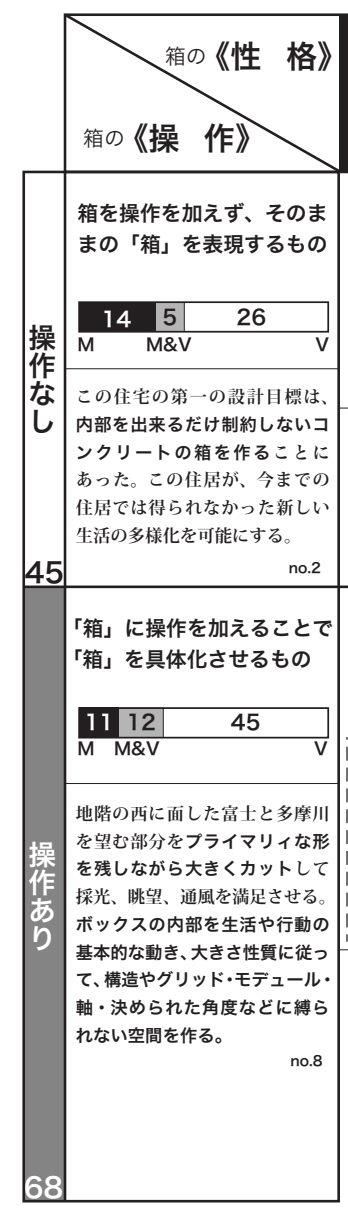

図4『箱の構成形式』
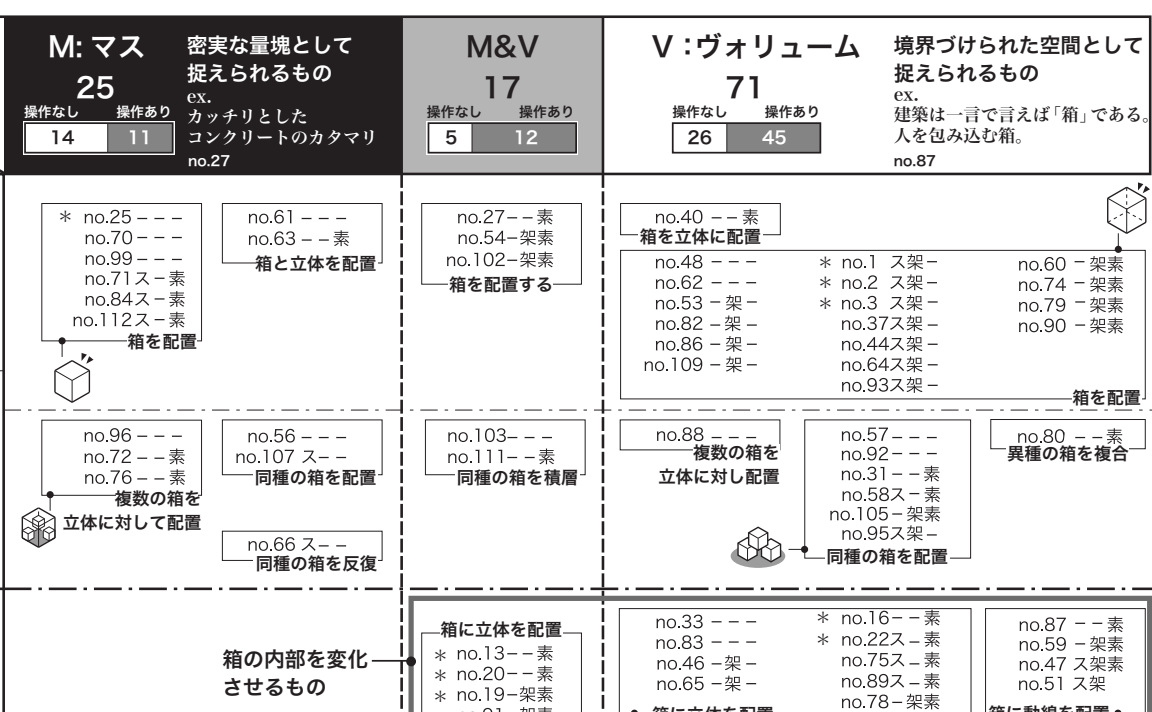

箱を配置

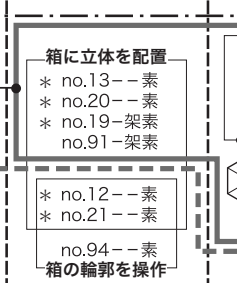

no.33---
no.83--
no.46-架-
no.65-架-
? 箱に立体を配置—

no.16--素
no.22
no.75 -
no

\begin{tabular}{|l|l|} 
no.22ス - 素 & $\begin{array}{l}\text { no. } 87-\text { - 素 } \\
\text { no.59 - 架素 }\end{array}$ \\
no.
\end{tabular}
no.75ス - 素 no.897 - 素 箱に立体を配置

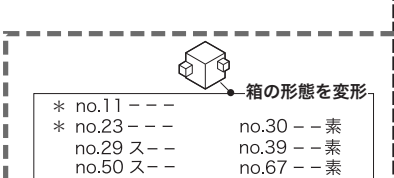

it)

*no.18箱の内部を分割 no.32-- - 素 no. $45---$

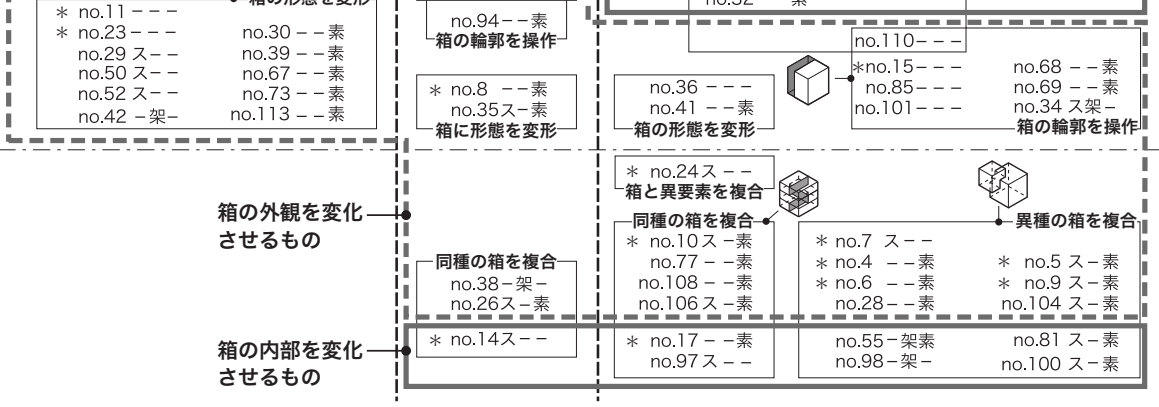

させるもの

注 : 図中の各まとまりに付されたダイアグラムは言説の意味内容を筆者が図化したもので、図面や写真等を分析して導いたものではない。

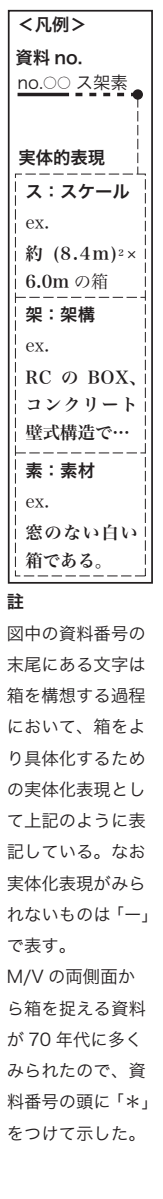


るヴォリュームとから「箱」の《性格》を捉える。マスは「カッチ リとしたコンクリートのカタマリ」（no.27, 1981）、「唐突に置かれ た杉板張りの箱は、周りの家並みとは不連続で異質な物体」(no.67, 1999）のように、箱」の物体としての特徴に着目しているものや、 「一見して不安定な直方体の箱」 (no.29, 1981) や「凹凸の少ない 単純形態」(no.91, 2003) など、その内側の空間に対する意識が みられず、形態的特徴のみを述べているものである。ヴォリューム は、「建築は一言で言えば「箱」である。人を包込む箱。」(no.85, 2002) や「“自然”や“私”を映し出す“カラッポの函”」(no.88, 2003）などのように、「箱」を境界付けられた空間として、殼の性 格を見出しているものである。

次に、「プライマリーな形を残しながら大きくカットして採光、 眺望、通風を満足させる」(no.8, 1971) のように、「箱」の具現化 の際に「箱」に加えられる変形や分割などの有無（[操作あり]、[操 作なし $]$ ) と、扱う「箱」の数（[単数 $] 、[$ 複数 $]$ ) を合わせて具体 的な内容を整理し、「箱」の《操作》として捉える。《操作》は建築

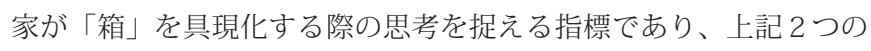
水準のうち［操作あり］と［複数］とはともに「箱」に関する実体 的側面や手法的側面の特性を複雑にするべクトルを備えると位置づ けられる。一方、[操作なし］と［単数］とは「箱」をそのまま用 い単純化のベクトルを備えるものだといえ、《操作》の有無によっ て建築家の単純性と複雑性の相反する思考の共存が捉えられるもの と考えられる。なお、[操作あり］に関しては、「箱」の外観を保ち ながらその内部を変化させるもの（[操作あり／内］）と、「箱」の
外観を変化させるもの（[操作あり／外]）との両方がみられた。

\section{3-2「箱」の《性格》と《操作》の関連}

前節で位置づけた「箱」の《性格》(マス/ヴォリューム) を横軸、 「箱」の《操作》を縦軸とし、具体的な《操作》の内容の整理とと もに全ての資料をあらわしたものが図 4 である。

まず、2つの《性格》について全資料を検討したところ、ヴォリュー ムがマスに比べ約 3 倍多くみられた（71 資料/25 資料、図 4 横軸）。 また、全資料中 17 資料に扔いてマスとヴォリューム双方の側面に 同時に着目して「箱」を捉えるものがみられた（図 4)。たとえば、 「きわめてプライマリイな箱になってきます。これは、私のつくり たい形態に沿うものなんです。…しいし、内側の生活の部分という のはそんな幾何形態とは全く関係はありません。ですから外を施主 と関係ないところで決めるかわりに、内側は木造で施主の好きにや らせてあげようということになりました。(no.13, 1972) のよう に「プライマリィな箱」の形態的な側面に着目しながらも、「内側 は施主の好きにやらせてあげよう」というように、その内部空間に ついても同時に思考するものである。このようなマス/ヴォリュー ムの両方の側面から「箱」を語る資料についてその年代を検討する と、1970 年代に偏って多くみられた（図 4 中*印資料)。こうし た傾向は、住宅の形と思想との関係を様々に模索した 1970 年代の 特徴の一端を示すものであると考えられる。

次に「箱」の《性格》と《操作》との関係から『箱の構成形式』 を位置付ける。《性格》において「箱」をヴォリュームと捉えた場合、 [操作あり]に偏りがみられ（マスで $11 / 25$ 資料に対し、ヴオリュー

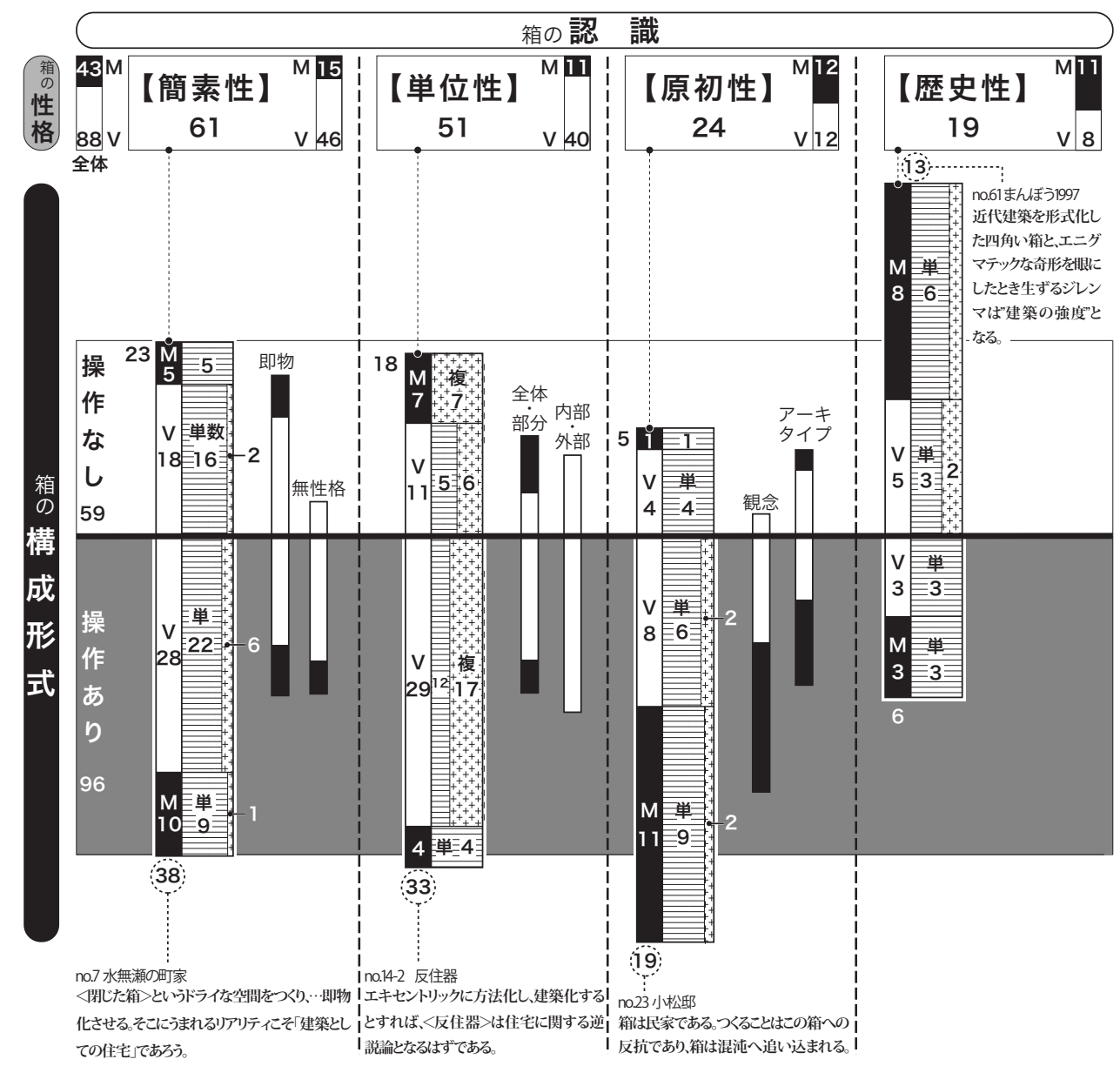

図5注

図中の数字は資料数を表すものとする。認識』ご

とに図2で捉えた認識の内容の小カテゴリの傾向 を並記した。 図6注)

各年代ごとのグラフの幅は、該当資料数の数をあ らわす。

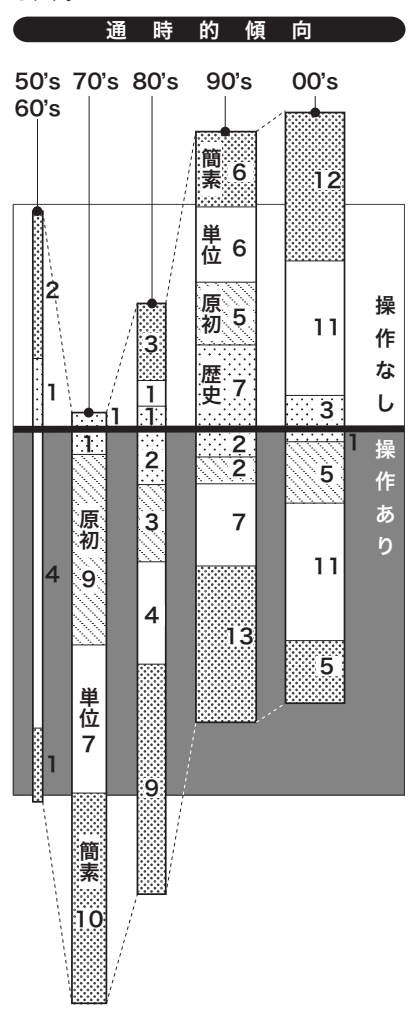

図 5 『箱の認識』と『箱の構成形式』との関係

図6 箱に投影された思考の通時的傾向 
ムで 45/71 資料)、特にヴォリューム／[単数］では [操作あり／内］ が多くみられた (27/45 資料)。一方「箱」をマスと捉えた場合、[操 作なしが比較的多くみられた。このことは、容器的特徴を 1 つの 「箱」について思考する際は、その内部への操作によって空間的設 えを構想する一方、容器的特徴を複数の「箱」について思考する際 は「箱」どうしの関係への考慮から外観の変化への操作が主流とな ることが考察される。また、量塊的特徴を思考する際は、マス／[操 作あり ］／複数］の資料がみられなかったことからも、外側から の俯瞰的視点のもと、「箱」自体への変形などの操作でなく、「箱」 の配置に焦点が置かれると考えられる。また、ヴォリュームとして の「箱」は変形・分割・加工などの操作によっても「箱」としての 性質は保持されると考えられ（操作を加えつつ「箱」と呼称する）、 一方でマスとしての箱は操作を施すことにより「箱」としての性質 が減じると考えられている(「箱」と呼称する際は操作を加えない) ことが傾向として考察される。

\section{4 「箱」に投影された建築家の思考}

\section{4-1『箱の認識』と『箱の構成形式』との関係}

まず、『箱の認識』と「箱」の《性格》との関係について検討した（図 5 上段)。『箱の認識』が【簡素性】、単位性】の場合、「箱」をヴオ リュームとして捉える傾向がみられる (図 5 注7)、横軸内の棒グラフ) のに対し、【原初性】、歴史性】の場合、全体の傾向と比較すると「箱」 をマスとして捉える傾向がみられた。この傾向を考察するにあたり、 2 章において【簡素性】と【単位性】は意味の付着しない存在とし て「箱」を捉える認識、【原初性】と【歴史性】は意味が内在した 存在として「箱」を捉える認識と位置付けたこと、および 3 章にお いて、マス、ヴォリュームがそれぞれ「箱」の量塊的・幾何的特徵、「箱」 の容器的・空間的特徵をそれぞれ示すものであると位置づけたこと を鑑み、上述した傾向を総合的に考察する。これより建築家は「箱」 の【簡素性】、単位性】といった意味が付着しない存在としての側 面に着目する際、その空間性を思考対象とし、その内部性とそこで の操作を問題とする傾向があるのに対し、【原初性】、歴史性】といっ た意味が内在した存在としての側面に着目する場合、その量塊性を 外側から思考対象とする傾向にあることが推察される。

次に、箱の認識』と「箱」の《操作》との関係について検討した（図 5 )。資料全体では [操作なし]に比べ [操作あり] が多くみられた。 各認識ごとにみると、【簡素性】、【単位性】、原初性】に拈いては、 全体的傾向に準拠して [操作あり] が多いのに対し、【歴史性】は [操作なし］への偏りが顕著であった。さらに「箱」の数では、【簡 素性】、原初性】、歴史性】では [単数] が多いのに対し、【単位性】 では［複数］となるものが多くみられた。ここで、意味が内在した 存在としての【原初性】と【歴史性】の 2 つの認識に関しての傾向 に着目すると、上述のように双方ともに「箱」の量塊性（マス）に 着目することに共通性がみられたが、【原初性】では报う「箱」に 操作が加えられる傾向があるのに対し、【歴史性】では操作が加え られない傾向を示した。このことは、建築家が「箱」に意味を担わ せる時にはその容器性・空間性よりも量塊性・幾何性に着目し、更 にその意味が建築の初源的な事柄である際は、その意味を起点とし て「箱」に操作を加えて、独自の意味の展開をはかろうとする傾向 にあり、一方その意味が近代主義を中心とした歴史的な事柄である
際は、「箱」との対応を保持するために操作が加えられないのでは ないかと考察される。

\section{4-2「箱」に投影された思考の通時的傾向}

ここまで検討した内容について通時的な検討を行う（図 6 注 7)、 付表)。【単位性】では、部分と全体の関係としての認識と内部と 外部の関係としての認識との双方ともに近年、数が増加している傾 向にあり、特に内部と外部の関係としての認識の増加傾向は顕著で あった。また、特に近年みられる傾向として、「箱の連結を表現す るような図式的表現に、ある限界を感じている。図式的表現という ことではなくて、もう少し空間的なものであって欲しいんです。」 （no.105, 2007）というように、部分と全体および内部と外部の双 方の関係についての認識をもつものがタられた。このことは、機能 や社会的要求から自律した建築を思考する際の手法的表現のための ッールとして捉えられていた「箱」から、より建築にまつわる現 象的事柄の思考を投影する対象としての「箱」へと変化している ことのあらわれと考えられる。【原初性】では、1970 年代は観念 的モデルとしての「箱」が多数みられる一方、近年ではアーキタ イプとしての「箱」が多くみられることが分かった。【歴史性】で は、1990 年代に顕著に近代主義の「箱」があらわれており、これ は 1990 年代のモダニズム回帰の動き ${ }^{17)}{ }^{18)}$ が影響したものと考え られる。また、「箱」という言葉を用いた設計論は、1970 年代か ら顕著に増え始めており乼 9)、1970 年代の『箱の認識』について 検討すると【歴史性】がほとんどみられなかった。

年代ごとに『箱の構成形式』について《操作》の有無を検討する と、相対的に $1970 \sim 80$ 年代では [操作あり] が多いのに対し、 1990-2000 年代は [操作なし］が多くみられた。さらに後者にお いて『箱の認識』の内容には差がみられ、1990 年代では、【原初 性】、歴史性】が比較的多くみられるのに対し、2000 年代では【簡 素性】、単位性】に偏りがみられた。これらのことは、「箱」が主 題として多くもちいられ始めた 1970 年代においては、意味の付着 しない単なる「箱」もしくは建築の普遍的モデルとしての「箱」が、 さまざまな操作を加える対象として着目され独自の設計論が展開さ れ、その後歴史上の「箱」(ここではそのほとんどが近代主義に関 する内容）が少しずつ参照され始めたと言える。そして 20 世紀末 の 1990 年代に大ると「箱」の初源的意味や歴史的意味が思考され るとともに、それぞれの意味と対応した「箱」がそのまま扱われ、 2000 年代に入ってそうした多くの意味や操作が相対化されるとと もに意味の付着しない「箱」の簡素性や単位性が単純にもちいるこ とがなされたと考えられる。

\section{5. 結}

以上本研究では、「箱」が単純な面による形態として構成される という量塊・幾何的特徵と、ものを納めるという容器・空間的特徴 とをもつことに着目し、建築の抽象モデルのひとつとして重要な概 念であることを指摘し、建築家が住宅作品の設計論において「箱」 を用いて創作の主題を提出する際の思考の意味内容を検討した。

第 1 章では、本研究の目的と背景について述べるとともに、建築 家が「箱」という言葉をどのように認識し設計の主題を投影してい るかという『箱の認識』と、抽象モデルとしての「箱」をどう具現 化していくかという『箱の構成形式』とから「箱」という言葉に投 
影した思考を捉えるという研究の方法の概要を提示した。

第 2 章では、箱の認識』の意味内容について検討した。その結果、 それらは【簡素性】、【単位性】、原初性】、【歴史性】の 4 つの意味 内容に分類できた。さらにこれらについて、【簡素性】と【単位性】 とが意味の付着していない存在としての「箱」であること、【原初性】 と【歴史性】とが意味が内在した存在としての「箱」であることを 3 章以降の分析・考察の前提として位置づけた。

第 3 章では、『箱の構成形式』の意味内容を量塊的、容器的特徴 を有する「箱」のどの水準に着目するかという「箱」の《性格》と、「箱」 をどのように構築するかという「箱」の《操作》の 2 つの水準から 捉えた。その結果、《性格》に関しては、「箱」の量塊性・幾何性に 着目したマスと「箱」の容器性・空間性に着目したヴォリュームと の 2 つ側面で整理できることをP・ジョンソンらの言説を参照し た上で位置づけて資料を分類し、《操作》に関しては、「箱」に分割 や切断などの操作を加えるか否か（[操作あり］、［操作なし］）と、 その際に用いる「箱」の数（[単数 $] 、[$ 複数 $]$ ) との側面から検討し た。さらに、「箱」をヴォリュームとして捉える際には操作を加え ることで空間表現を模索する傾向にあるのに対し、「箱」をマスと して捉える際には操作を加えずにその量塊性による単純さを求める という傾向が捉えられた。

第 4 章では、『箱の認識』と『箱の構成形式』との関係を「箱」 という言葉に投影された建築家の思考として検討した。その結果、 『箱の認識』が【簡素性】、単位性】の際は「箱」をヴォリューム として捉え、そこに操作を加えるものが多くみられた。また【原初 性】、歴史性】の際は双方ともに「箱」をマスと捉える傾向に共通 性がみられるものの、前者では「箱」に操作を加え、後者では操作 を加えずそのまま表現に持ち込む傾向が捉えられた。また、通時的 な検討の結果、「箱」という言葉が顕著にあらわれ始めた 1970 年 代においては、箱」は操作対象として存在し、その際用いられる「箱」 は【簡素性】、単位性】、原初性】として認識されており、【歴史性】 がごくわずかにしかみられなかった。それに対し 1990-2000 年代 において「箱」は表現にそのまま持ち込まれる傾向が読み取れたが、 1990 年代ではその「箱」は【原初性】、歴史性】として捉えられ、 近年では【簡素性】、【単位性】に偏る傾向がみられた。つまり、建 築家が「箱」を設計論に用い始めた際、「箱」は近代主義建築との 関連よりもむしろ対立する概念として存在していたといえる。それ が 1990 年代に入り、ポストモダニズムの終焉を迎えモダニズムへ と思考の対象が回帰した際、「箱」という言葉に内在するモダニズ ムを再認識し、そのまま建築表現へと引用されたと考えられる。

注

注 1 )「箱」という言葉を作品名に含んだ連作を展開している建築家として、 宮脇檀（《ボックス》シリーズ）、難波和彦（《箱の家》シリーズ）、葛 西潔 (《木箱》シリーズ) があげられる。

注 2 ）横山正は著書において「ぼくたちが箱というと何かその容れものそれ 自体とその内部の空虚とをイメージするのは、たしかに東洋（中略） の考えであって、ヨーロッパ流に言えば、箱といえばまずその箱のう ちなるオブジェがイメージされるのが筋なのであろう。」(参考文献 $2 、$ p.28）と述べている。また田中純は参考文献 3で、箱の容器性につい て、その中に収められるものが順序だてられない断片であることにつ いて、「断片の囲い込み効果とは、断片がつねにあらかじめそれを内 包する「箱」の存在を前提としているということにほかならない。テ クストの断片化と箱のパラダイムは対になっている。と述べている。

注 3 ) 広辞苑第四版（岩波書店）による。

注 4 ）本研究において「箱」に類する言葉としたのは、「はこ」「ハコ」、函」、 「box」、「ボックス」の5つである。

注 5 ) 藤岡、佐藤によれば、日本での建築関連の言説における「空間」とい う語は、明治・大正時代に「「物と物との間」、「すきま」、「あるまと まりをもった広がり」という意味に用いられ」てはいたものの、建築 文献に頻繁に登場するようになったのは 1950 年代頃からであり、「最 も巧みに活用した」のは丹下健三と丹下研究室であった (参考文献 5 )。 本研究において「箱」のもつ容器的側面が「空間」と密接に関わるこ とからも、資料の対象を戦後とするのは妥当であると考える。

注 6 ) KJ 法とは民族地理学の分野で川喜田二郎によって考案されたものとし て知られており、何らかの問題提起から状況把握、そしてそれに対す る解決方法のプロセスまでの一連の方法をいう（参考文献 15）。ここ ではその中で、ある問題をめぐって問題のあり得る情報を集め、定性 的データとし、意味の分かるような全体像とするまでのプロセスを狭 義での KJ 法としている。本研究では、著者 4 名によって KJ 法を行い、 それぞれによる判断が異なる場合は、そのそれぞれの判断根拠と、資 料総体における判断の是非を議論し、判断の根拠について一致が得ら れた時点でふたたび全ての資料について、再度 KJ 法による分析を試 み、この過程を最終的に全ての資料について判断が一致するまで繰り 返し行うという方法をとっている。川喜田二郎は著書『発想法』で「累 積的 KJ 法」としてこのような分析方法の妥当性を説明している。(『発 想法』pp.111-112)

注 7 ）全 113 資料に対し同一の資料が複数のカテゴリーに該当することがあ るため、図 2 、図 5 、図 6 においての合計数は 155 となっている。

注 8 ) 本論中の引用部の後の括弧内の数字は、資料番号と資料の掲載年を示 す。また、本文での引用箇所は分析対象の一部である。

注 9 ) 全資料中、50 年代が 3 資料、60 年代が 1 資料、70 年代が 21 資料、 80 年代が 13 資料、90 年代が 32 資料、00 年代が 43 資料である。 参考文献

1 ）ル・コルビュジエ：プレシジョン, 鹿島出版会, 1984.1

2）横山正：箱という劇場, 王国社, 1989.3

$3)$ 田中純：箱をめぐる戦略——都市のレディ・メイド, 10+1, No.24, pp.2-10, 2001.6

4 ）塩崎太伸, 奥山信一：現代日本の建築家の設計論にみられる空間をも ちいた創作言語——空間という語を利用した建築的思考の文脈と形 式に関する研究, 日本建築学会計画系論文報告集, Vol.73, No.633, pp.2333-2340, 2008.11

5 ）藤岡洋保，佐藤由美：建築雑誌に示された日本の建築界への「空間」 という概念の導入と定着, 日本建築学会計画系論文報告集, No.447, pp.109-118, 1993.5

6 ）佐々木夕介, 山田深：現代日本住宅の創作における与条件と建築の関係 イメージ——建築家の言説にみられる空間的思考に関する研究, 日本建 築学会計画系論文報告集, No.608, pp.173-179, 2006.10

7 ）竹内宏俊, 岩岡竜夫, 他: 建築におけるスケールの概念について, 日本 建築学会計画系論文集, No.594, pp.231-236, 2005.8

8 ）奥山信一, 他：建築家の言説にみられる現代住宅作品の空間モデル ——建築家の創作論に関する研究, 日本建築学会計画系論文報告集, No.456, pp.123-134, 1994.2

9 ) 水上優：F.L. ライトの建築思想における「成長」の概念, 日本建築学会 計画系論文報告集, No.563, pp.313-320, 2003.1

10)アルド・ファン・アイクの建築思想における方法概念「イマジネーション」 の意味, 日本建築学会計画系論文報告集, No.616, pp.199-206, 2007.6

11）川道麟太郎：近代にみられる建築の概念における機械のアナロジー—— 建築におけるアナロジーに関する研究 その 3 , 日本建築学会計画系論 文報告集，No.409，pp.123-132，1990.3

12) 内藤麻美, 四ヶ所高志, 奥山信一, 塩崎太伸, 稲用隆一：住宅設計論 にみられる「箱」という言葉の認識——建築家の住宅設計論に関する研 究, 16, 日本建築学会大会学術講演梗概集 F-2, pp.721-722, 2010.7

13）内藤麻美, 奥山信一, 四ヶ所高志, 塩崎太伸, 稲用隆一：住宅設計論に みられる「箱」という言葉をもちいた建築的思考——建築家の住宅設計 論に関する研究, 17, 日本建築学会大会学術講演梗概集 F-2, pp.723$724,2010.7$

14）磯崎新：政治的であること, 新建築, 新建築社, 1998.5

15）川喜田二郎：発想法, 中央公論社, 1967.6

16) H-R・ヒッチコック, P・ジョンソン : インターナショナル・スタイル, 鹿島出版会, 1978.6

17）石井和紘：3つの近代, 新建築, 新建築社, 1990.2

18）安藤忠雄 : 建築の周辺から, 新建築, 新建築社, 1990.8 


\title{
A STUDY ON THE FRAMEWORK OF ARCHITECTURAL THOUGHTS WITH THE WORD "BOX" AS A DESIGN THEME OF CONTEMPORARY JAPANESE HOUSES
}

\author{
Taishin SHIOZAKI*, Asami NAITO**, Takashi SHIKASHO*** \\ and Shin-ichi OKUYAMA**** \\ * Assist. Prof., Dept. of Architecture and Building Engineering, Tokyo Tech, Dr. Eng. \\ ** Shinkenchiku-sha Co., Ltd., M. Eng. \\ *** Assist. Prof., Dept. of Architecture, Fukuoka University, Dr. Eng. \\ **** Prof., Dept. of Architecture and Building Engineering, Tokyo Tech, Dr. Eng.
}

The aim of this study is to clarify the framework of architectural thoughts with the word "box" through analyzing design theories of contemporary Japanese houses.

Firstly the conceptural recognitions for "box" are classified by KJ method through analyzing articles written as design theory for houses by architect. These are classified into four categories showed in Fig. 2 (Simplicity, Unitarity, Primordiality, and Histricity). Category [Simplicity] and [Unitarity] has larger number than the other two. Additionaly it can be pointed out that category [Simplicity] and [Unitarity] consist of the meaning of "box" itself, on the other hand category [Primordiality] and [Histricity] are adhered to by strong meaning. That strong meaning have been nurtured by long, multifaceted histories into the conception "box".

Secondly the organization forms of "box" are analyzed from two aspects. The one is the characteristics of "box" which is classified into Mass type and Volume type, and the other is the operations on "box" which shows the number of "box" to operate or not to operate. The characteristics of "box" (Mass type / Volume type) is defined with refered to the book "International style" written by H R Hitchcock and P Johnson. In that book they mentioned the characteristics of Volume as the first principle of International style. In this thesis, Mass type is defined as a characteristic to capture the feature of the whole form or shape and Volume type to capture the feature of inner space. After the analysis the number of Volume type is larger than Mass type and used to operate on "box" (Fig. 4).

Finally relations between the conceptural recognitions and the organization forms of "box" are analyzed totally including a chronological consideration. There are strong relations between the conceptural recognition's category [Primordiality] / [Histricity] and Mass type, and between category [Simplicity] / [Unitarity] and Volume type. Then in the former case used to have some operation on "box", on the other hand in the latter case category [Primordiality] used to have operation but category [Histricity] does rarely have operation. This means that when architects think some meaning which is related to architecture originaly like [Primordiality] / [Histricity] they used to think with Mass type of "box" which has the feature of the whole form or shape. Especially it is inferable that the meaning of [Histricity] used to be used with the "box" without any operation because of it's strong correspondence between the meaning and the form or shape. Plus when architects concentrate on the meaning of "box" itself like [Simplicity] / [Unitarity] they used to operate someting with a thought of inner space of "box". From a chronological consideration, it is found out the article with the word "box" increased from 1970s. As for operations, during 1970s and 1980s "box" used to be operated something but during 1990s and 2000s architect used to use "box" without operation. 